\title{
Studi Deskriptif Kualitatif Loyalitas Brand Wardah di Sekolah Tinggi Ilmu Kesehatan Indonesia Maju
}

\author{
Firdha Alwani Lestari ${ }^{1}$, Febriansyah Nataly $^{2}$, Fatima ${ }^{3}$ \\ ${ }^{1,2,3}$ Sekolah Tinggi Ilmu Komunikasi Indonesia Maju \\ Email correspondent: firda@gmail.com
}

\begin{abstract}
Abstrak
Loyalitas terhadap merek adalah gambaran perilaku preferensi konsumen terhadap suatu merek dengan melakukan pembelian berulang. Hal ini sangat berpengaruh bagi suatu perusahaan untuk dapat bertahan dan tetap eksis di tengah persaingan pasar, khususnya untuk produk Wardah yang telah digunakan oleh banyak konsumen tak terkecuali mahasiswi. Penelitian ini bertujuan untuk mengetahui bentuk loyalitas brand Wardah yang digunakan mahasiswa kebidanan STIKIM. Metode pada penelitian ini yaitu kualitatif dimana menjelaskan dan mengetahui bentuk loyalitas para konsumen Wardah di jurusan kebidanan STIKIM dengan cara pengumpulan data observasi, angket kuesioner, dan wawancara. Tahap teknik analisa data yang dilakukan penelitian ini adalah reduksi data, penyajian data, dan penarikan kesimpulan. Hasil penelitian ini membuktikan bahwa kepercayaan mahasiswa terhadap merek Wardah sangat berpengaruh kepada pembentukan kepuasan serta loyalitas terhadap produk tersebut. Kesimpulannya bahwa reputasi produk memegang peran penting dalam melakukan keputusan pembelian ulang. Saran yang dapat diberikan melakukan inovasi baru terhadap produk tersebut.
\end{abstract}

Kata Kunci: loyalitas, merek, kepercayaan

\begin{abstract}
Brand Loyalty is a description of behavior preference of consumers on a brand with recurring purchases of products. It does matter in a company for survive and remain in existence in the middle market competition, especially for Wardah products that has been used by many consumers no exception a college student .This study aims to know the form of brand loyalty Wardah in STIKIM students majoring Midwifery. A method of the experimental on this research is the qualitative where explain and knows the form of loyalty of Wardah consumer in STIKIM students majoring Midwifery by means of data collection observation, the questionnaire, and the interview. The stage data available for analysis technique surveyed this is data reduction, presentation of data, and the withdrawal of conclusion. The result of this research prove that students faith against brand Wardah very affect to the formation of satisfaction and loyalty of that product.
\end{abstract}

Keywords: loyalty, merk, trust 


\section{Pendahuluan}

Perilakunya (terutama perilaku beli) adalah wujud dari kekuatan tawar yang merupakan salah satu kekuatan kompetitif yang menentukan intensitas persaingan dan profitabilitas perusahaan. ${ }^{1}$ Perilaku belanja tersebut berdampak pada semakin ketatnya persaingan antar perusahaan industri perawatan pribadi dan kosmetik. Hal ini terbukti dengan banyaknya jenis kosmetika beredar baik produksi dalam negeri maupun produksi luar negeri. Banyaknya produk kosmetika dipasaran mempengaruhi sikap seseorang terhadap pembelian dan pemakaian barang. Salah satu produk yang sangat diikuti oleh kaum wanita saat ini adalah perawatan kecantikan kulit dan kosmetik. Hal ini dikarenakan adanya pergeseran pola konsumsi masyarakat yang semula cukup menggunakan bedak wajah untuk mempercantik diri beralih ke produk pelengkap lainnya seiring dengan meningkatnya pendapatan dan kebutuhan akan kosmetik lainnya.

Di Indonesia sendiri perkembangan industri kosmetik tergolong solid, hal ini terlihat dari peningkatan industri kosmetik pada tahun 2018 tumbuh 20\% atau empat kali lipat dari pertumbuhan ekonomi nasional pada tahun 2017. Industri kosmetik di dalam negeri bertambah sebanyak 153 perusahaan pada tahun 2017, sehingga saat ini jumlahnya mencapai lebih dari 760 perusahaan. ${ }^{2}$

Pemasaran merupakan salah satu kegiatan pokok yang dilakukan perusahaan untuk mencapai tujuan. Salah satu aset penting dalam suatu perusahaan adalah merek. Merek menjadi sebuah kontrak kepercayaan (a contract of trust) antara perusahaan dan konsumen karena ia menjamin adanya konsistensi bahwa sebuah produk akan selalu dapat menyampaikan nilai yang diharapkan konsumen darinya. Pemberian merek yang unik dan kreatif sehingga membangun citra merek atau brand image yang positif juga merupakan salah satu strategi untuk bersaing. ${ }^{3}$

Loyalitas pelanggan menunjukan pada kesetiaan pelanggan pada objek tertentu, seperti pada merek, produk, jasa atau toko. Pada umumnya merek sering kali dijadikan sebagai objek loyalitas pelanggan. Loyalitas merek (brand loyality) mencerminkan loyalitas pelanggan pada merek tertentu. Loyalitas pelanggan memberikan dampak yang signifikan bagi profitabilitas perusahaan. Pelanggan yang loyal kemungkinan akan menunjukan sikap dan prilaku positif, seperti pembelian ulang merek yang sama dan rekomendasi positif yang dapat mempengaruhi pelanggan lain untuk menggunakan merek tersebut (Arlan, 2006: 63). Loyalitas terhadap merek adalah perilaku mengutamakan sebuah merek dengan melakukan pembelian berulang. ${ }^{4}$ Arlan mengatakan, bahwa hubungan pelanggan dan loyalitas tampak menjadi lebih kompleks dari pada yang diharapkan. Didalam perspektif relasional, trust (kepercayaan) merupakan variabel yang memediasi hubungan antara sikap tertentu dan behavioral outcomes. Kepuasan yang didorong oleh kepercayaan pada suatu merek akan lebih menjelaskan loyalitas sesungguhnya. ${ }^{4}$

Pada konteks pemasaran industri, kepercayaan dibangun dalam hubungan person- to-person. Pemahaman brand trust berbeda dengan kepercayaan interpersonal, karena merek merupakan simbol dan simbol tersebut sulit untuk merespon pelanggan. Untuk memperoleh loyalitas dalam pasar saat ini, pemasar harus memfokuskan pada pembentukkan dan pemeliharaan kepercayaan dalam hubungan pelanggan dengan merek.

Setyawan mengemukakan bahwa dalam mengukur kepercayaan terhadap merek diperlukan penentuan atribut dan keuntungan dari sebuah merek. Kepercayaan merupakan variabel mediasi dalam hubungan jangka panjang antara perusahaan dengan konsumen. Kepercayaan terhadap merek tersebut pada akhirnya akan membangun sebuah loyalitas merek. Seseorang konsumen mengalami suatu pengalaman di dalam mengkonsumsi suatu merek sehingga pada akhirnya akan menyebabkan loyalitas merek. $^{5}$

Perusahaan baik yang menjual produk berupa barang dan juga yang berupa jasa terus menggunakan berbagai cara berbisnis guna mendapatkan keputusan konsumen untuk membeli. Keputusan pembelian konsumen merupakan hal yang paling penting dalam kemajuan perusahaan, 
karena dengan semakin besar konsumen ingin membeli produk atau jasa dalam perusahaan, maka akan semakin besar

peluang perusahaan tersebut untuk mendapatkan profit dan pelanggan tetap. Keputusan pembelian tidak hanya dapat menjadi peluang bagi perusahaan untuk mendapatkan keuntungan dari segi bisnis, namun juga dengan semakin banyaknya konsumen membeli suatu produk, maka perusahaan tersebut dan konsumen akan loyal kepada perusahaan tersebut. Untuk membuat seseorang memutuskan membeli produk yang perusahaan berikan, banyak cara yang bisa dicapai oleh perusahaan misalnya dengan memberikan kualitas terbaik dari produk itu sendiri.

Produk yang berkualitas tinggi akan memberikan keuntungan lebih, yang berarti konsumen akan bersedia membeli suatu barang yang berkualitas tinggi dengan harga yang relatif terjangkau dan melakukan pembelian ulang. Kualitas produk merupakan driver atau penggerak bagi kepuasan pelanggan. Di dalam industri yang mengedepankan produk berupa barang sebagai inti usaha, kualitas produk memegang peranan yang sangat penting dalam strategi bertahan dan membentuk kepercayaan konsumen terhadap merk dan memutuskan untuk membeli.

Wardah adalah salah satu merek produk berlandaskan islami yang diproduksi oleh PT. Paragon Technology And Innovation, dibuat oleh Indonesia dan tidak mengandung bahan berbahaya serta telah memiliki sertifikat halal dari lembaga LP POM MUI. Wardah Cosmetics dan Skincare menghasilkan produk yang memiliki keunggulan berbeda dengan merek lainnya, selain memiliki kualitas produk dan citra merek yang baik, Wardah lebih menonjolkan terhadap kehalalan dari bahan kosmetik serta skincare tersebut. Produk kosmetik dan skincare halal makin menjadi kebutuhan perempuan, terutama bagi pengguna hijab. Sertifikasi halal baik pada penggunaan bahan maupun cara produksi menjadi salah satu pertimbangan kalangan pengguna hijab dalam memilih kosmetik dan skincare. Produk dengan sertifikasi halal tak lantas diperuntukkan bagi perempuan berkerudung atau muslim. Perempuan manapun yang ingin tampil menarik namun tak berlebihan dapat memilih merek produk semacam ini. ${ }^{6}$

Produk Wardah selain dari keamanan dan sertifikasi halalnya, produk yang dihasilkan juga memberikan manfaatnya dengan baik. Salah satu produk kosmetik halal dan aman yaitu Wardah Cosmetics merupakan pioneer produsen kosmetik halal di Indonesia yang memanfaatkan momentum tersebut serta mendapatkan anugrah halal 2012 dari LPPOM MUI yang dinilai berdasarkan program sosialisasi dan promosinya yang menempatkan aspek halal sebagai selling point.

Kesadaran masyarakat Indonesia terhadap penampilan yang cukup tinggi, dapat terlihat dari meningkatnya penjualan produk kosmetik dan perawatan kecantikan terlebih pada kalangan mahasiswi. Peran mahasiswi dalam perilaku konsumsi kosmetik dan skincare dapat dikatakan cukup signifikan, karena pada saat ini para mahasiswi dalam menjalani kesehariannya tak dapat terlepas dari penggunaan kosmetik maupun skincare. Sehingga saat ini perusahaan tak hanya memperhatikan kebutuhan kosmetik dan skincare dari konsumen yang telah bekerja saja, namun kebutuhan dari konsumen mahasiswi juga mendapat perhatian. ${ }^{7}$

Mahasiswa Sekolah Tinggi Ilmu Kesehatan Indonesia Maju (STIKIM) terdiri dari mahasiswamahasiswi yang sedang maupun akan berkecimpung dalam dunia kesehatan, dimana mereka juga terbiasa menggunakan make-up maupun produk skincare untuk menunjang penampilan mereka. Mahasiswi jurusan Kebidanan misalnya, disamping tugas kuliah, praktek, maupun kunjungan lapangan, tidak dipungkiri apabila mereka sering berburu produk make up maupun skincare. Tidak terkecuali untuk produk Wardah yang terkenal dengan kehalalan-nya karena sebagian besar mahasiswi jurusan kebidanan menggunakan jilbab. Berdasarkan latar belakang tersebut, maka penelitian ini berusaha mengetahui dan menganalisis tanggapan konsumen terhadap produk Wardah dan hal-hal apa sajakah yang berpengaruh terhadap keputusan pembelian ulang yang mengacu kepada loyalitas merek.

\section{Metode}




\section{JIKOM}

Jurnal Ilmiah Komunikasi

Volume 12, No.01, Maret. 2020

Metode yang digunakan penelitan kualitatif adalah penelitian yang menggunakan metode observasi, wawancara, analisis isi, dan metode pengumpulan data lainnya untuk menyajikan responrespon dan perilaku subjek. ${ }^{8}$

Sifat penelitian yang digunakan adalah studi deskriptif yang merupakan suatu metode dalam meneliti status kelompok manusia, suatu objek, suatu set kondisi, suatu sistem pemikiran ataupun suatu kelas peristiwa pada masa sekarang. ${ }^{9}$

Penelitian dilakukan di STIKIM (Sekolah Tinggi Ilmu Kesehatan Indonesia Maju) Jurusan Kebidanan Eskstensi Tahun ajaran 2018 semester ganjil pada bulan Juli sampai dengan Agustus 2019. Sumber informasi dalam penelitian ini terdiri dari Manager Sales Wardah Cibinong City Mall sebagai keyinforman serta dua mahasiswa STIKIM sebagai infoman.

Pencatatan sumber data utama melalui wawancara atau pengamatan berperanserta, yang merupakan hasil usaha gabungan dari kegiatan melihat, mendengar, dan bertanya. Sumber data pada penelitian ini terbagi dua yaitu data primer yang merupakan hasil dari observasi dengan wawancara mendalam (indepth interview) dari pihak-pihak terkait. Data sekunder diperoleh melalui data berbentuk dokumentasi melalui buku, web, artikel, dan foto untuk mendukung penelitian yang diangkat. Dokumen menjadi alat untuk melengkapi keterangan yang telah diberikan oleh informan. ${ }^{10}$

Teknik pengumpulan data dari penelitian ini dilakukan dengan observasi merupakan pemilihan, pengubahan, pencatatan serangkaian perilaku dan suasana yang berkenaan dengan organisasi, sesuai dengan organisasi, sesuai dengan tujuan-tujuan empiris". Observasi dilakukan di STIKIM untuk melakukan pembanding antara hasil interview dengan apa yang terjadi di lapangan. ${ }^{11}$

Angket atau kuesioner adalah teknik pengumpulan data melalui formulir- formulir yang berisi pertanyaan-pertanyaan yang diajukan secara tertulis pada seseorang atau sekumpulan orang untuk mendapatkan jawaban atau tanggapan dan informasi yang diperlukan oleh peneliti. untuk memperoleh data tentang tanggapan mahasiswi STIKIM jurusan Kebidanan tentang produk Wardah dan sebesar apakah loyalitas mereka menggunkan produk tersebut. Kemudian dari hasil uji kuesioner, akan di pilih responden dengan hasil point terbesar. ${ }^{12}$

Selanjutnya dilakukan wawancara dari hasil kuesioner dengan hasil point terbesar. Wawancara adalah tanya jawab lisan antara dua orang atau lebih secara langsung, wawancara berguna untuk : pertama, mendapatkan data ditangan yang pertama (primer). Kedua, pelengkap teknik pengumpulan lainnya. Ketiga, menguji hasil pengumpulan data lainnya. ${ }^{13}$

Pengumpulan data selesai, tahap analisis data dilakukan. Data dianalisis menggunakan metode deskriptif kualitatif yaitu dengan mendeskripsikan secara menyeluruh data yang didapat selama proses penelitian. Miles dan Huberman mengungkapkan bahwa dalam mengolah data kualitatif dilakukan melalui tahap reduksi, penyajian data, dan penarikan kesimpulan. ${ }^{14}$

\section{Hasil dan Pembahasan}

Gambar 1 Diagram Lingkaran Loyalitas Brand Wardah

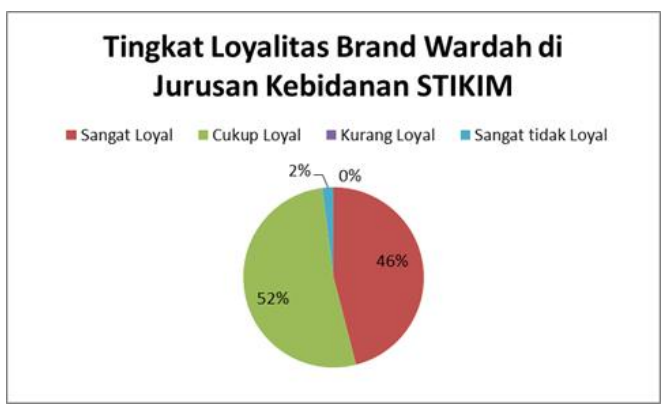

Sumber: Data Primer 2019

Available online http://journal.stikom-ima.ac.id/ 
Setelah dilakukan uji penyebaran angket kuesioner kepada 50 responden mahasiswi jurusan Kebidanan STIKIM, kemudian peneliti mengambil 2 orang responden dengan kategori nilai tertinggi. 2 orang mahasiswi ini merupakan pelanggan yang sangat setia menggunakan produk Wardah. Selanjutnya 2 orang engan nilai loyal tertinggi diikutkan untuk wawancara mendalam terkait bentuk loyalitas mereka terhadap Brand Wardah.

Terbentuknya pelanggan yang loyal tidak lepas dari adanya rasa kepuasan setelah membeli dan menggunakan produk. Sesudah konsumen membeli produk, konsumen akan merasa puas atau bisa jadi tidak puas akan masuk dalam perilaku setelah pembelian. Apabila produk dibawah harapan konsumen, maka konsumen akan merasa kecewa, dan apabila produk memenuhi harapannya, maka konsumen akan terpuaskan, apabila melebihi harapannya, konsumen akan merasa senang.

Loyalitas pelanggan bagi Wardah merupakan hal yang sangat penting dalam membantu kelangsungan hidup perusahaan di tengah persaingan pasar industri kosmetik dan skincare yang sangat ketat saat ini. Dari awal peluncurannya hingga sekarang, Wardah terus konsisten menciptakan berbagai produk, menciptakan berbagai macam strategi yang kuat untuk mendapatkan posisi tersendiri di mata pelanggan.

Loyalitas konsumen adalah suatu tindakan atau sikap dari konsumen yang merasa senang atas pemberian jasa terhadap konsumen, ciri-ciri konsumen yang loyal yaitu: ${ }^{15}$ (1) Menggunakan Produk. Ketika pembeli sudah komit/loyal terhadap suatu merek, ia akan terus menggunakan produk tersebut tanpa beralih ke merek lain apapun yang terjadi. (2) Merekomendasikan, ciri selanjutnya pelanggan yang loyal adalah merekomendasikan produk tersebut kepada orang lain. Karena konsumen tersebut merasa menyukai dan puas akan manfaat yang diberikan produk tersebut, ia tidak akan segan-segan mempromosikan produk tersebut kepada orang lain. (3) Menyampaikan hal-hal yang bersifat positif. Pengalaman yang didapat oleh konsumen dan berdampak baik akan membentuk persepsi baik pula bagi konsumen. Dampak positif yang didapati konsumen akan menggiring konsumen untuk menyukai produk yang selanjutnya ia akan setia menggunakan produk tersebut. Maka, jika di kemudian hari ketika ada kerabat maupun rekan yang menanyakan pendapat perihal merek produk tersebut, maka konsumen tersebut akan menyampaikan hal-hal baik/positif tentang merek tersebut. (4) Mempertimbangkan kembali untuk membeli. Ketika konsumen telah merasa puas akan sebuah merek, ia menjadi sangat loyal terhadap merek tersebut dan akan membeli produk merek tersebut kembali.

Terbentuknya Pelanggan yang loyal tidak dapat diperoleh tanpa kepercayaan terhadap merek (Brand Trust) Wardah itu sendiri. Dari sudut pandang konsumen, Brand trust akan mempengaruhi customer satisfaction (kepuasan pelanggan) dan customer loyalty (kesetiaan pelanggan). Brand trust bersandar pada penilaian konsumen yang subjektif didasarkan pada persepsi yaitu: ${ }^{16}$

Persepsi konsumen terhadap manfaat yang dapat diberikan produk/merek. Dari hasil wawancara, informan I memiliki kulit yang sensitif yang berkemungkinan memicu masalah pada kulit apabila menggunakan produk yang tidk sesuai dengan kebutuhan kulitnya. Namun, ketika ia mencoba menggunakan Wardah, hasilnya tidak memberikan dampak buruk terhadap kulitnya. Dari sini di dapati bahwa informan I memiliki persepsi bahwa produk Wardah memberikan manfaat bagi kebutuhannya. Persepsi konsumen akan reputasi merek. Pernyataan tersebut membenarkan pada pernyataan poin kedua, yaitu dimana karena reputasi 'halal' yang dimiliki Wardah, menggiring persepsi konsumen untuk mencoba menggunakan produknya.

Persepsi konsumen akan kesamaan kepentingan dirinya dengan penjual. Informan I menginginkan agar Wardah terus melakukan inovasi untuk menciptakan produk agar konsumenkonsumen lain seperti dirinya bisa terus menikmati produk-produk terbaik Wardah, begitupun dengan yang disampaikan oleh Key Informan bahwa Wardah selaku seller terus berupaya melakukan inovasi untuk terus mendapatkan kepercayaan dan kesetiaan dari para konsumennya. 


\section{JIKOM \\ Jurnal Ilmiah Komunikasi}

Volume 12, No.01, Maret. 2020

Persepsi sejauh mana konsumen dapat mengendalikan penjual. Dari apa yang disampaikan oleh Key Informan, semakin jelas bahwa persepsi konsumen tersebut dapat mengendalikan penjual, yaitu membantu Wardah memberikan ide untuk mengembangkan produk sesuai kebutuhan para konsumen.

Tiga faktor yang mempengaruhi kepercayaan merek. Ketiga faktor tersebut berhubungan dengan tiga entitas yang tercangkup dalam hubungan antara merek dan konsumen. Ketiga faktor tersebut adalah: ${ }^{17}$

\section{Karakteristik Merek}

Dalam konteks hubungan merek dan konsumen, kepercayaan konsumen dibangun berdasarkan padareputasi merek, prediktabilitas merek, dan kompetensi merek. (a) Reputasi merek berkenaan dengan opini dari orang lain bahwa merek itu baik dan dapat diandalkan. Reputasi merek dapat dikembangkan bukan saja melalui periklanan dan public relation, tetapi juga dipengaruhi oleh kualitas dan kinerja produk. Konsumen akan mempersepsikan bahwa sebuah merek memiliki reputasi baik jika merek tersebut dapat memenuhi harapan mereka, maka reputasi yang baik itu akan memperkuat kepercayaan pelanggan. (b) Prediktabilitas merek adalah merek yang memungkinkan pelanggan untuk mengharapkan bagaimana sebuah merek akan memiliki performance pada setiap pemakaian. Prediktabilitas merek dapat meningkatkan keyakinan konsumen karena konsumen mengetahui bahwa tidak ada sesuatu yang buruk akan terjadi ketika menggunakan merek tersebut. Reputasi Wardah yang halal kemudian berhasil menggiring persepsi konsumen informan I bahwa produk tersebut pastilah aman dan tidak akan berdampak buruk bagi dirinya, hal tersebut masuk kedalam prediktabilitas karena sebelumnya konsumen telah memprediksi sebelum akhirnya memutuskan untuk membeli dan menggunakan produk tersebut. (c) Kompetisi merek adalah merek yang memiliki kemampuan untuk menyelesaikan permasalahan yang dihadapi oleh pelanggan, dan dapat memenuhi kebutuhannya. Ketika diyakini sebuah merek itu mampu untuk menyelesaikan permasalahan dalam diri pelanggan, maka pelanggan tersebut mungkin berkeinginan untuk meyakini merek tersebut. informan merasa Wardah dapat memenuhi kebutuhannya yakni warna-warna soft yang dimiliki Wardah dalam seri eyeshadownya, meski mungkin banyak merek lain memiliki hal yang serupa dan lebih bagus, tapi informan I merasa ia merasa tidak menemukan hal serupa di merek yang lain.

\section{Karakteristik perusahaan}

Karakteristik perusahaan yang ada dibalik suatu merek juga dapat mempengaruhi tingkat kepercayaan konsumen terhadap merek tersebut. Pengetahuan konsumen tentang perusahaan yang ada dibalik suatu merek produk. Karakteristik ini meliputi reputasi suatu perusahaan, motivasi perusahaan, dan integritas perusahaan.

Konsumen - Karakterstik Merek Karakteristik konsumen - merek dapat mempengaruhi kepercayaan terhadap merek. Karakteristik ini meliputi kemiripan antara konsep emosional dengan kepribadian merek, kesukaan terhadap merek, dan pengalaman terhadap merek.

Beragam produk dan derasnya arus informasi mengakibatkan merek menjadi hal pertama yang diingat oleh konsumen. Oleh karena itu, Wardah berusaha untuk menanamkan merek produknya dalam benak konsumen, sehingga mereka akan menjadi loyal pada merek Wardah.

Keuntungan yang diperoleh dari kepuasan konsumen sangatlah besar, akan tetapi saat ini keputusan konsumen tidak lagi menjadi tujuan akhir dari proses bisnis suatu perusahaan. Banyaknya perusahaan yang mengandalkan kepuasan konsumen sebagai keberhasilan di kemudian harinya, tapi akhirnya harus kecewa karena mendapati para pelanggannya yang merasa puas berbelanja pada produk pesaing tanpa ragu-ragu. Tetapi, konsumen yang sangat loyal kepada suatu merek tidak akan dengan mudah memindahkan pembeliannya ke merek lain apapun yang terjadi dengan merek tersebut. 


\section{JIKOM \\ Jurnal Ilmiah Komunikasi}

Volume 12, No.01, Maret. 2020

Dua orang informan Pelanggan setia produk Wardah di jurusan kebidanan STIKIM sepakat untuk terus menggunakan produk Wardah dalam jangka waktu panjang terkait kualitas yang telah diberikan Wardah, mereka bahkan tak segan merekomendasikan dan mempromosikan produk Wardah kepada kerabat maupun orang-orang sekitar, menceritakan hal-hal positif selama mereka menggunakan Wardah, dan memutuskan untuk melakukan pembelian ulang dalam jangka waktu ke depan. Maka dari itu Wardah terus berusaha menanamkan merek produk dalam benak konsumen sehingga mereka menjadi setia akan produk merek Wardah.

Bagi Wardah, mempertahankan kesetiaan para konsumen jauh lebih sulit seiring makin berkembangnya para pesaing dalam industri kosmetik dan skincare, sehingga Wardah perlu terus mengembangkan usahanya dengan melakukan berbagai inovasi-inovasi produknya agar kepuasan dan kesetiaan pelanggan tidak mudah luntur akibat dari pergeseran daya saing kompetitor-kompetitor hebat diluar.

Dari hasil penelitian yang dilakukan di jurusan kebidanan STIKIM membuktikan bahwa kepercayaan mereka terhadap produk merek Wardah sangat berpengaruh kepada pembentukan kepuasan serta loyalitas terhadap produk merek Wardah. Mereka yang setia terhadap merek Wardah, tidak mudah memindahkan pembeliannya ke produk merek lain apapun yang terjadi dengan produk tersebut.

Persepsi pelanggan terhadap manfaat yang dapat diberikan oleh produk merek Wardah, persepsi pelanggan akan reputasi merek Wardah, persepsi pelanggan akan kesamaan kepentingan antara apa yang diharapkan oleh pelanggan dengan merek Wardah, dan persepsi sejauh mana pelanggan dapat mengendalikan Wardah adalah persepsi para pelanggan Wardah yang mempengaruhi dalam hubungan kepercayaan merek Wardah.

Karakteristik merek Wardah yang didasarkan pada konsep 'HALAL' juga menjadi faktor utama para pelanggan memutuskan untuk membeli dan menggunakan produk Wardah. Konsep halal yang dimiiki Wardah berhasil menggiring opini pelanggan bahwa kandungan yang terdapat pada produk Wardah sangat aman digunakan meskipun dalam jangka waktu panjang sekalipun. Keunikan konsep serta karakter Wardah yang identik dengan wanita lembut dan modern berhasil ditanamkan Wardah melalui iklan lewat peran para Brand Ambassador yang hadir di berbagai media elektronik, media cetak maupun online juga menjadi poin untuk menggiring opini konsumen wanita indonesia khususnya wanita muslim untuk menggunakan produk Wardah.

\section{Kesimpulan}

Loyalitas Brand Wardah di jurusan Kebidanan Ekstensi Tahun ajaran 2018 di STIKIM dipengaruhi oleh adanya Brand Trust (Kepercayaan Merek) yang selanjutnya berkembang membentuk citra positif dari merek tersebut (Brand Image).

Dari hasil penelitian, reputasi halal yang dimiliki Wardah yang memegang peranan paling besar dalam melakukan keputusan pembelian karena reputasi halal menggiring pemikiran konsumen bahwa produk tersebut aman di gunakan dan bebas dari bahan- bahan berbahaya sehingga aman untuk di konsumsi dalam jangka panjang. Reputasi halal ini kemudian berhasil menggiring prediksi pelanggan bahwa kandungan yang terdapat pada produk Wardah sangat aman digunakan dalam jangka waktu ke depan. Peran pada Celebrity Endorser juga berpengaruh terhadap kompetisi merek Wardah seiring dengan persaingan di dunia industri kosmetik dan skincare yang semakin berkembang.

Dari hasil penelitian membuktikan pelanggan yang telah loyal terhadap produk merek Wardah di jurusan kebidanan STIKIM sepakat untuk menggunakan produk merek Wardah dalam jangka waktu panjang, merekomendasikan produk Wardah ke orang- orang sekitar, menceritakan hal-hal positif tentang produk Wardah berdasarkan pengalamannya, dan mempertimbangkan kembali untuk membeli produk merek Wardah dalam jangka waktu ke depan. 


\section{JIKOM \\ Jurnal Ilmiah Komunikasi}

Volume 12, No.01, Maret. 2020

\section{References}

1. Larry A. Samovar \& Richard E. Porter. Komunikasi Lintas Budaya. Jakarta: Salemba Humanika;2010

2. Everett M.Rogers.Diffusion of Innovations, 5th Edition. SIMON \& SCHUSTER;2012

3. Bill Yenne. 100 Peristiwa yang Berpengaruh Di Dalam Sejarah Dunia. Karisma;2012

4. Dalma. Keterampilan Menulis. Jakarta: Rajawali;2012

5. https://www.kompasiana.com/aguspribadi1978/5518be3a81331197669df09d/mengembangkan-jalan-ceritasebuah-cerpen.

6. https://id.wikipedia.org/wiki/Karikatur.

7. Daryanto. Media Pembelajaran. Bandung: PT Sarana Tutorial Nurani Sejahtera;2915

8. https://www.boc.web.id/statistik-pengguna-digital-dan-internet-indonesia-2019/.

9. https://www.slideshare.net/Cardy69/makalah-pameran-seni-rupa.

10. epository.upi.edu/16884/2/S_PSR_1005657_Chapter1.pdf.

11. Djelantik. Estetika Sebuah Pengantar. Bandung: Masyarakat Seni Pertunjukan Indonesia, bekerja sama dengan kuBuku;1999

12. Sugiyono. Metodelogi Penelitian Kuantitatif, Kualitatif dan R\&D. Kota Tanggerang - Cipodoh, Banten;2017

13. Nanang Martono, metode. 2010. PenelitianKuantitatif Analisis Isi Dan Analisis Data Sekunder. Jakarta:Rajawali Pres.

14. Arikunto, S. Prosedur Penelitian Suatu Pendekatan Praktik. Jakarta:Rineka Cipta;2016

15. Yusup F. Uji. 2018. Vliditas dan Reabilitas Intrumen Penelitian Kuantitatif. J Tarb J Ilmu Kependidikan.

16.Zakina. Nilai Estetik Batik Tulis Pewarna Alam Karya Industri Kebon Indah Bayat, Kelaten Jawa Tengah.Universitas Negeri Yogyakarta;2015

17. Agus F. Tangyong. Pengembangan Anak Usia Taman Kanak-Kanak. Jakarta: Grasindo;2010

18. Sugiarti. Estetika Dalam Novel Jatisaba Karya Ramayda Akmal. Universitas Muhamadiah Malang;2016

19. Nurgiyantoro, Burhan. Sastra Anak Pengantar Pemahaman Dunia Anak. Yogyakarta : Universitas Gajah Mada;2013

20. Fatimah, Fatimah. "Komunikasi Persuasif Agen Asuransi Dalam Merekrut Calon Agen (Studi Kasus Tentang Perekrutan Calon Agen Dalam Meningkatkan Penjualan Polis di Asuransi PT. AXA)." Jurnal Ilmiah Komunikasi (JIKOM) STIKOM IMA 10.02 (2018): 110-116 